Especial: Profesores de Estudios Generales Investigan

I Sección: Historia, institucionalidad, prensa y creencias

\title{
La Constitución Política de 1949, sus raíces histórico políticas durante el
} período 1940-1948

\author{
Vladimir de la Cruz \\ Universidad de Costa Rica \\ vladimirdelacruz@hotmail.com \\ http://orcid.org/0000-0002-8083-7294
}

Recibido: 31 de noviembre de 2019

Aceptado: 31 de enero de 2020

Resumen: El 70 aniversario de la Constitución Política de Costa Rica es un buen momento para recordar los eventos previos a la emisión de la Carta Magna. ¿Cómo debemos ver y apreciar la existencia de esta Constitución Política? ¿Cómo entender las circunstancias y sucesos históricos que condujeron al momento histórico que le dieron origen? ¿Qué valor tiene la Constitución Política actual?

El contexto que produce la convocatoria de la Asamblea Nacional Constituyente de 1949, que dio origen a la actual Constitución Política, fue el resultado de una grave confrontación social y política que se venía dando durante la década de 1940 y especialmente, a partir del Pacto producido, en 1943, entre el Gobierno del Dr. Rafael Ángel Calderón Guardia, y su Partido Republicano, Monseñor Víctor Manuel Sanabria Martínez, Jefe de la Iglesia Católica, su Obispo, y Manuel Mora Valverde, Secretario General del Partido Comunista de Costa Rica.

El repaso de esta década que a nivel internacional fue tan convulsa y que llenó al país de luchas ideológicas y problemas económicos, es clave para comprender el significado de la emisión de la Constitución de 1949.

Palabras clave: Costa Rica; década de 1940, partido comunista; Manuel Mora V.; Rafael Ángel Calderón G.

The Political Constitution of 1949 , its historical political roots during the period 1940-1948

\section{(c) (i) (2)}

La Revista Estudios es editada por la Universidad de Costa Rica y se distribuye bajo una Licencia Creative Commons Atribución-NoComercial-CompartirIgual 3.0 Costa Rica. Para más información envíe un mensaje a 


\section{Especial: Profesores de Estudios Generales Investigan}

Abstract: The 70th anniversary of the Political Constitution of Costa Rica is a good time to remember the events prior to the issuance of the Magna Carta.

How should we see and appreciate the existence of this Political Constitution? How to understand the circumstances and historical events that led to the historical moment that gave rise to it? What is the value of the current Political Constitution?

The context produced by the convening of the National Constituent Assembly of 1949, which gave rise to the current Political Constitution, was the result of a serious social and political confrontation that was taking place during the 1940s and especially, from the Pact produced, in 1943, between the Government of Dr. Rafael Ángel Calderón Guardia, and his Republican Party, Monsignor Victor Manuel Sanabria Martínez, Head of the Catholic Church, its Bishop, and Manuel Mora Valverde, General Secretary of the Communist Party of Costa Rica.

The review of this decade that was so convulsive at the international level and that filled the country with ideological struggles and economic problems, is key to understanding the meaning of the issuance of the 1949 Constitution.

Keywords:Costa Rica; 1940's decade; Communist Party; Manuel Mora V.; Rafael Ángel Calderón G.

(Conferencia dictada en la Biblioteca Nacional a propósito de la "Conmemoración de los 70 años de la Constitución Política de 1949", el 14 de noviembre del 2019. La actividad fue organizada por la Escuela de Estudios Generales y su Cátedra Enrique Macaya Lahmann, de la Universidad de Costa Rica y la Biblioteca Nacional del Sistema Nacional de Bibliotecas)

Nos reúne la "Conmemoración de los 70 años de la Constitución Política de 1949", que se ha venido realizando con distintos eventos y actos públicos, que exaltan la vigencia de la actual Constitución Política.

¿Cómo debemos ver y apreciar la existencia de esta Constitución Política? ¿Cómo entender las circunstancias y sucesos históricos que condujeron al momento histórico que le dieron origen? ¿Qué valor tiene la Constitución Política actual?

Trataré de explicar y dar respuesta a estas y otras interrogantes.

El contexto que produce la convocatoria de la Asamblea Nacional Constituyente, de 1949, que dio origen a la actual Constitución Política, fue el resultado de una 
Especial: Profesores de Estudios Generales Investigan

grave confrontación social y política que se venía dando durante la década de 1940, y especialmente a partir, a mi modo de ver, desde el Pacto producido, en 1943, entre el Gobierno del Dr. Rafael Ángel Calderón Guardia, y su Partido Republicano, Monseñor Víctor Manuel Sanabria Martínez, Jefe de la Iglesia Católica, su Obispo, y Manuel Mora Valverde, Secretario General del Partido Comunista de Costa Rica.

A partir de ese momento el cuadro político nacional se alteró profundamente, aunque ya estaba alterado por las medidas antinazis que se venían dando desde 1942.

Un sector político visualizó un peligro comunista en desarrollo y alcance que había que evitar, tanto por el escenario internacional que se atendía como la fuerza social que el comunismo criollo iba teniendo, y su posible influencia, a partir de ese momento en el Gobierno, a pesar de que el Pacto no les produjo a los comunistas más influencia de la que ya tenían en el Congreso Nacional y en la vida social. No negociaron puestos en el Gabinete con ministros.

\section{Diciembre de 1941, el inicio del viraje}

Eran tiempos duros en el mundo y en Costa Rica. A nivel internacional estaba la lucha intensa contra el avance del nazi fascismo en Europa, donde se había desarrollado una alianza muy importante de la Unión de Repúblicas Socialistas Soviéticas, de Inglaterra y la Francia Libre, principalmente la Francia del General Charles De Gaulle. Los Estados Unidos se integraron a esta lucha hasta diciembre de 1941, cuando fueron bombardeados en sus bases militares en Hawai y las Filipinas por los japoneses, aliados de Hitler y de Mussolini.

Estos sucesos de diciembre de 1941 iniciaron los cambios en Costa Rica que condujeron, finalmente, a los eventos de 1948, que provocaron la llamada Guerra Civil y sus consecuencias político institucionales.

\section{(C) $(0 \bigcirc$}

La Revista Estudios es editada por la Universidad de Costa Rica y se distribuye bajo una Licencia Creative Commons Atribución-NoComercial-CompartirIgual 3.0 Costa Rica. Para más información envíe un mensaje a revistaestudios.eeg@ucr.ac.cr. 
Especial: Profesores de Estudios Generales Investigan

El ataque de los japoneses a Estados Unidos provocó, a solicitud del propio Presidente de los Estados Unidos, que el Dr. Rafael Ángel Calderón Guardia declarara la guerra a Italia, Alemania y Japón, "por solidaridad con el gobierno y el pueblo norteamericano, alevosamente atacados", como se justificó, el 7 de diciembre de 1941, por parte de don Alberto Echandi, Secretario de Relaciones Exteriores, ante el Congreso Constitucional, para autorizar al Gobierno a declarar la guerra.

Esta Declaración de Guerra se justificaba además por lo acordado, con participación de Costa Rica, en la Conferencia Interamericana de Consolidación de la Paz que se reunió en Buenos Aires en diciembre de 1936, en la Octava Conferencia Internacional Americana, celebrada en Lima en diciembre de 1938, donde se adoptó una declaración de Principios de Solidaridad de América, así como en la ratificación de la Declaración de Lima que se hizo en la Reunión de Consulta de los Ministros de Relaciones Exteriores de las Repúblicas Americanas, celebrada, en Panamá, en setiembre y octubre de 1939, y que se volvió a ratificar en la Segunda Reunión de Consulta entre los Ministros de Relaciones Exteriores de las Repúblicas Americanas, celebrada en La Habana en julio de 1940.

El 8 de diciembre de 1941, el Congreso dio la autorización para declarar la guerra, comunicado firmado por el Presidente del Congreso, Teodoro Picado Michalski, y ordenado para su publicación en la Gaceta ese mismo día, por el Presidente Rafael Ángel Calderón Guardia.

Así se declaró el estado de guerra contra el Imperio del Japón el 8 de diciembre de 1941, el primer país del continente en hacerlo, y tres días después, el 11 de diciembre se declaraba la guerra a Alemania e Italia.

Se justificaba la guerra, además, porque se afirmaba que estos tres países habían esclavizado a los pueblos de Holanda y Bélgica, siendo la Primera Dama de entonces, doña Ivonne Clays Spoelders, ciudadana belga, lo que debe haber influido enormemente.

\section{(c) (†) (-)}

La Revista Estudios es editada por la Universidad de Costa Rica y se distribuye bajo una Licencia Creative Commons Atribución-NoComercial-CompartirIgual 3.0 Costa Rica. Para más información envíe un mensaje a revistaestudios.eeg@ucr.ac.cr. 


\section{La lucha antinazi fue clave en la década}

\section{Especial: Profesores de Estudios Generales Investigan}

Esta sola situación alteró el ambiente político interno. El Partido Comunista venía insistiendo, durante ese año de 1941, en su Plan Nacional de Emergencia para salir de la Crisis de Guerra, que ya había empezado a hacerse sentir gravemente en el país.

Era el Partido Comunista el primer bastión importante de esa lucha antinazi por cuanto veían el peligro del avance de Hitler sobre la Unión Soviética, como sucedió, aun cuando Hitler y Stalin habían firmado el Pacto de no agresión del 23 de agosto de 1939, el Pacto Ribbentrop - Molotov.

El Dr. Rafael Ángel Calderón Guardia había llegado a la presidencia apoyado e impulsado por León Cortés, por la Iglesia Católica y por el sector capitalista, una parte de origen alemán, que estaba aliado a León Cortés, desde su presidencia. A León Cortes los comunistas lo consideraban un filofascista.

En el país había actividad pronazi y antinazi. La pronazi dirigida desde el Club alemán. La antinazi tuvo distintos frentes, el "Comité France Amérique", donde estaban, entre otros, Alejandro Alvarado Quirós, Otilio Ulate Blanco, Guillermo Padilla Castro, León Pacheco Solano, el "Comité Femenino France Amérique", el "Grupo por la Francia Libre", integrado por jóvenes de la Escuela de Derecho, el "Frente Nacional Antinazi" donde estaban Marcial Rodríguez Conejo, que llega a ser Presidente de la Asamblea Nacional Constituyente unos años después, J. Francisco Trejos, Fernando Valverde Vega, quien llega a ser miembro de la Junta de Gobierno en 1948, Víctor Manuel Quesada, Manuel Mora Valverde, Francisco Vargas Vargas, Adolfo Herrera García y Manuel Picado Chacón.

Apoyaban al Frente Anti Nazi Julio Acosta García, Tomás Soley Güell y Adriano Urbina. Había también un "Comité Pro De Gaulle", el Frente Nacional Anti Nazi del Magisterio", el "Frente Juvenil Democrático", el "Comité de Unificación de las Asociaciones Anti Totalitarias", donde estaban entre otros, Fernando Valverde

La Revista Estudios es editada por la Universidad de Costa Rica y se distribuye bajo una Licencia Creative Commons Atribución-NoComercial-CompartirIgual 3.0 Costa Rica. Para más información envíe un mensaje a revistaestudios.eeg@ucr.ac.cr. 
Especial: Profesores de Estudios Generales Investigan

Vega, Adriano Arié, Edgar Brenes, Hortencia Zelaya, Hilda Chen Apuy, Bejos M. Yamuni y Manuel Mora Valverde, y casi una decena más de organizaciones antinazis.

El Centro de Estudios para los Problemas Nacionales, recién fundado, le da apoyo al Gobierno en su declaratoria de guerra, lo mismo que el Partido Demócrata, y el Partido Comunista de igual manera, especialmente a partir del rompimiento del Pacto de Stalin con Hitler, cuando Alemania avanza sobre la Unión Soviética, aunque ya había censurado el ataque en Hawaii.

El Gobierno de Calderón Guardia venía impulsando medidas de seguridad, que se van fortaleciendo en el curso de los meses. Se cancelaron las credenciales diplomáticas de los representantes de Alemania, se creó en 1942 la Junta Nacional de Defensa Civil, se estableció censura de la correspondencia con esos países enemigos y se señaló que los súbditos del Eje que realizaren actos contra el Estado serían enviados a campos de concentración o expulsados del país. Empezaron a detenerse y encarcelarse ciudadanos alemanes e italianos, se tomó el Club Alemán y la Casa Italia. Algunos ciudadanos detenidos, cerca de 300, fueron enviados a campos de concentración en Estados Unidos.

Como medidas también se creó la Junta de Custodia de la Propiedad Enemiga, se hicieron listas públicas de ciudadanos, llamadas listas negras, que eran intervenidos, y se les expropiaron propiedades. El Centro de Estudios para los Problemas Nacionales combate las "listas" diciendo que el Gobierno las aprovecha para meter ciudadanos opositores a su gestión política. También se creó la Junta de Defensa Económica, la Junta de Racionamiento de Gasolina, y se emitieron Bonos de Defensa Nacional

Cuando había terminado la Guerra, el Gobierno de Teodoro Picado Michalski, se opuso al regreso de esos ciudadanos, lo que provocó protestas de sus esposas costarricenses e hijos.

\section{(a) $\mathbb{Q} \Theta($}

La Revista Estudios es editada por la Universidad de Costa Rica y se distribuye bajo una Licencia Creative Commons Atribución-NoComercial-CompartirIgual 3.0 Costa Rica. Para más información envíe un mensaje a revistaestudios.eeg@ucr.ac.cr. 


\section{Especial: Profesores de Estudios Generales Investigan}

Con ellos se dio una época de abusos y despojos de propiedades y negocios. El Obispo Víctor Manuel Sanabria Martínez apoyó a las mujeres de estos expatriados. El Partido Comunista no estaba de acuerdo con el retorno de todos y solo de aquellos que estudiándolos se considerara que no eran un peligro para el país.

También durante la Guerra Mundial el gobierno suspendió, las Garantías Individuales de la Constitución de 1871, entonces vigente, por debate parlamentario realizado el 9 de diciembre de 1941, dirigido por Teodoro Picado Michalski, con la oposición del Partido Demócrata a estas medidas. El diputado Otto Cortés Fernández, hijo del Presidente León Cortés Castro, advirtió que estas medidas podían influir en el próximo proceso electoral de diputados de 1942 y en el nacional de 1944. Los comunistas no votaron la medida en diciembre, pero si lo hicieron en marzo de 1942 considerando que en ese momento sí había necesidad de ello. El Diario de Costa Rica combatió estas medidas como contrarias a las tradiciones y principios de libertad del país. El expresidente Ricardo Jiménez tampoco estuvo de acuerdo con la suspensión de las Garantías Individuales.

La suspensión se realizó por períodos largos y cortos. La suspensión de las Garantías Individuales se mantuvo hasta el 16 de agosto de 1945, cuando bajo el gobierno de Teodoro Picado Michalski, su Secretario de Gobernación, Fernando Soto Harrison, pidió al Congreso la derogatoria total de esa suspensión, momento que se atizó el debate contra el Gobierno de Picado Michalski y contra el del Dr. Calderón Guardia.

Hasta mayo de 1942 el Gobierno de Estados Unidos informaba que los submarinos alemanes habían hundido 28 buques en distintas partes del continente, sobre el supuesto que servían para transportar combustibles y suministros a los aliados en Europa. En esos días se dieron una serie de incidentes en el país con buques alemanes y japoneses que habían atracado en puertos nacionales.

\section{(2) $(100$}

La Revista Estudios es editada por la Universidad de Costa Rica y se distribuye bajo una Licencia Creative Commons Atribución-NoComercial-CompartirIgual 3.0 Costa Rica. Para más información envíe un mensaje a 


\section{Especial: Profesores de Estudios Generales Investigan}

\section{La expulsión de José Figueres}

El 2 de julio de 1942 por la noche fue atacado y hundido el vapor San Pablo, en Puerto Limón, con saldo de 24 costarricenses muertos, cuando realizaba actividades de carga y descarga de bananos.

El hundimiento del vapor San Pablo incrementó los sentimientos antinazis. Todos los sectores de país condenaron ese ataque. El 4 de julio se desarrolló una gran manifestación de protesta, con discursos de Manuel Mora Valverde, Rafael Ángel Calderón Guardia, Fernando Lara Bustamante y otros dirigentes nacionales.

La marcha terminó violentamente con ataques, saqueos y agresiones a 123 establecimientos de alemanes y de ciudadanos de los países considerados enemigos. Esto provocó reacciones fuertes contra el Gobierno.

Por este motivo el ciudadano José Figueres Ferrer pronunció un fuerte discurso por radio contra el Gobierno y el Presidente Calderón Guardia, discurso que el gobierno consideró peligroso para la seguridad nacional. Le impidieron terminar su discurso y le detuvieron.

Su discurso atacaba la orientación del Gobierno ante la Guerra Mundial, hablaba sobre los sucesos ocurridos el 4 de julio, y vinculaba a los comunistas como responsables de esos actos. Ello llevó al Gobierno a considerar a José Figueres filo fascista, lo acusaron de nazi fascista, y de tener negocios con ciudadanos alemanes.

La detención de José Figueres provocó una gran agitación política nacional. El 9 de julio en el Congreso se dio un gran debate a propósito de su detención, donde llegaron a calificar a José Figueres como el primer reo político después de la Dictadura de los Tinoco.

El 11 de julio de 1942 José Figueres fue deportado a México, llevando una nota, de Manuel Mora Valverde, al líder sindical mexicano Vicente Lombardo Toledano para que le ayudara en lo que pudiera.

\section{(c) (i) (2)}

La Revista Estudios es editada por la Universidad de Costa Rica y se distribuye bajo una Licencia Creative Commons Atribución-NoComercial-CompartirIgual 3.0 Costa Rica. Para más información envíe un mensaje a revistaestudios.eeg@ucr.ac.cr. 
Especial: Profesores de Estudios Generales Investigan

La expulsión del territorio nacional de José Figueres, por órdenes de la Embajada Americana, le hizo víctima y le empezó a levantar su imagen como un líder político, que hasta ese momento no lo era.

El Gobierno de Calderón Guardia desde su inicio había trazado sus inquietudes sociales, con la Caja Costarricense del Seguro social y con la reapertura de la Universidad de Costa Rica. En sus primeros meses también impulsó con su Ministro de Educación, Luis Demetrio Tinoco, la derogación de las leyes liberales, que era su compromiso con la Iglesia Católica, para el apoyo a su candidatura presidencial en 1939.

La declaratoria de Guerra a los países del Eje acercó al Partido Comunista al Gobierno y a la Iglesia. Después de diciembre de 1941 se inició un intenso proceso de acercamiento en proporción a la vez del alejamiento que del Gobierno hacía del cortesismo político y sus aliados, y del gran capital alemán. La situación era grave. El Dr. Calderón Guardia hasta pensó la posibilidad de alejarse del Gobierno y hasta un intento de Golpe de Estado se fraguó en su contra.

La Iglesia bajo la dirección del Arzobispo Sanabria Martínez era sumamente anticomunista. El objetivo del Jefe de la Iglesia estaba en derogar las leyes liberales y abrirle de nuevo el espacio a la Iglesia católica en la institucionalidad que había perdido con las leyes liberales de 1882-1884.

\section{La esencia del Pacto entre la Iglesia, el Gobierno y el Partido Comunista}

El impulso de las políticas sociales del Dr. Rafael Ángel Calderón Guardia acercó al Partido Comunista a su apoyo y defensa. El marco de la lucha antinazi, después de la declaratoria de guerra al Eje fascista, más los unió, sobre todo cuando hubo intentos de derrocar al Presidente Calderón Guardia. Ello los hizo avanzar hacia la consolidación de impulsar como política nacional la aprobación del Capítulo de las Garantías Sociales y del Código de Trabajo, que resultaban también de una larga

\section{(C) $(\Theta \circ$}

La Revista Estudios es editada por la Universidad de Costa Rica y se distribuye bajo una Licencia Creative Commons Atribución-NoComercial-CompartirIgual 3.0 Costa Rica. Para más información envíe un mensaje a 


\section{Especial: Profesores de Estudios Generales Investigan}

lucha social de los trabajadores costarricenses, que se había venido plasmando en diversas leyes laborales y de carácter social, en la existencia de la Secretaria de Trabajo desde 1928, en el Artículo 10 de la Constitución Política de 1917 que había anticipado las políticas sociales de seguridad social.

La Iglesia condicionó el apoyo a la alianza del Gobierno con el Partido Comunista, en los siguientes aspectos: 1.- que el Partido Comunista cambiara de nombre, 2.que el Partido Comunista reconociera que la Reforma Social que se impulsaba tenía tradición e inspiración socialcristiana, 3.- que el Partido Comunista aceptara la creación de una nueva Central Sindical dirigida por la Iglesia, la Confederación de Trabajadores Costarricenses Rerum Novarum, 4.- que el Partido Comunista cediera, a esta nueva organización sindical, uno de los dos asientos que tenía la Confederación de Trabajadores de Costa Rica, que era la organización sindical dirigida por los comunistas, que era única y unitaria hasta ese momento. Los comunistas por su parte condicionaron que la Iglesia emitiera un pronunciamiento autorizando a los católicos a ingresar al Partido Comunista en su nueva denominación, Vanguardia Popular.

Así, el Partido Comunista el 13 de junio de 1943, acordó cambiar de nombre y llamarse Vanguardia Popular, acordó también ceder de la Junta Directiva de la CCSS a Enrique Benavides Chaverri, para que ingresara el Padre Benjamín Núñez Vargas, sacerdote al que el Arzobispo Sanabria Martínez había enviado a prepararse al extranjero en asuntos sociales, y a su hermano, Santiago, en asuntos cooperativos, para disputarle también al Partido Comunista, en ese campo, su influencia entre el campesinado nacional. Aceptó el Partido Comunista la nueva organización sindical impulsada por la Iglesia. Con el cambio de nombre del Partido Comunista se hizo un planteamiento programático, que se le hizo llegar al Arzobispo.

El Arzobispo Sanabria Martínez, por su parte emitió, el mismo día de la noticia de cambio de nombre y de Programa, una nota de recibo y señaló que "Ios católicos

La Revista Estudios es editada por la Universidad de Costa Rica y se distribuye bajo una Licencia Creative Commons Atribución-NoComercial-Compartirlgual 3.0 Costa Rica. Para más información envíe un mensaje a revistaestudios.eeg@ucr.ac.cr. 


\section{Especial: Profesores de Estudios Generales Investigan}

podían ingresar a la nueva organización, Vanguardia Popular, sin cargo de conciencia alguna".

Así se avanzó, especialmente en el segundo semestre de 1943, en apoyo público a la Reforma Social y el Código de Trabajo en trámite legislativo. Grandes marchas y movilizaciones, giras del Dr. Calderón Guardia por distintas partes del país, para levantarle la imagen que tenía muy caída. En agosto se aprobaron las Garantías Sociales y el Código de Trabajo, el 26 de agosto, fecha del cumpleaños de Manuel Mora, para que entraran en vigencia el 15 de setiembre de 1943, fecha que se denominó día de "La Segunda Independencia", día que se celebró un magno desfile por la capital que terminó con un recorrido en jeep abierto con los cuatro pilares políticos del momento, Rafael Ángel Calderón Guardia, Monseñor Víctor Manuel Sanabria Martínez, Teodoro Picado Michalski y Manuel Mora Valverde.

De este desfile está la foto histórica donde aparecen montados en el jeep Rafael Ángel Calderón Guardia, Monseñor Víctor Manuel Sanabria Martínez, Teodoro Picado Michalski y Manuel Mora Valverde.

La reacción no se hizo esperar. Ataques principalmente al Jefe de la Iglesia, pintándole en caricaturas hoces y martillos, agrupándose los sectores conservadores en ver como frenaban esa alianza. El Centro de Estudios para los Problemas Nacionales editorializando en la Revista Surco contra las Garantías Sociales Ilamándolas "opio del pueblo".

Frente a los ataques al Arzobispo, él se defendió diciendo: "Yo soy el Jefe de la Iglesia. El Dr. Calderón Guardia es el Jefe del Gobierno. Cuando yo estaba viendo pasar el desfile al frente de la Catedral, el Dr. Calderón Guardia detuvo el jeep, se bajó y me invitó a acompañarlos en el trayecto del desfile que quedada. Ante una invitación pública del Jefe de Gobierno al Jefe de la Iglesia, yo, no podía hacerle un desaire público. Por eso me monté con ellos, porque también estoy de acuerdo con las Reformas aprobadas".

\section{(ब) $(\Theta \odot$}

La Revista Estudios es editada por la Universidad de Costa Rica y se distribuye bajo una Licencia Creative Commons Atribución-NoComercial-CompartirIgual 3.0 Costa Rica. Para más información envíe un mensaje a 


\section{Las elecciones de 1944}

\section{Especial: Profesores de Estudios Generales Investigan}

La alianza forzada alrededor de las Garantías Sociales y el Código de Trabajo, de las Ilamadas Reformas Sociales, condujo naturalmente a impulsar una alianza política electoral, de los Partidos Republicano, de gobierno y de Vanguardia Popular, para las elecciones de 1944, que se plasmó en la coalición política electoral que se llamó Bloque de la Victoria. La oposición política propuso nuevamente a León Cortés como candidato a la Presidencia.

Los comunistas no estaban muy de acuerdo con la candidatura de Teodoro Picado Michalski, porque cuando había sido Secretario de Educación, en el último Gobierno de Ricardo Jiménez, 1932-1936, se había dedicado a perseguirlos y expulsarlos del magisterio nacional, incluso había cerrado la escuela infantil que tenía Carmen Lyra y porque exaltaba, analizando la situación de Polonia, desde la I Guerra Mundial hasta 1936, al Mariscal Joseph Pilsudski, de Polonia, quien se había desempeñado como dictador desde 1926 hasta 1936, cuando muere, y a quien se le consideraba sumamente reaccionario. Por ello, aprueban la candidatura unitaria de Teodoro Picado Michalski pero firmando un pacto hecho público donde se reservaban el derecho de crítica pública.

\section{Las elecciones de 1944}

Las elecciones de 1944, todavía en el marco del final de la II Guerra Mundial, se daban en un ambiente sumamente tenso.

El resultado de las elecciones fue a favor de Teodoro Picado Michalski, con cuestionamiento grave sobre su triunfo electoral. La oposición acusaba de que se había producido un fraude. Se dice que Teodoro Picado afirmó: "Aún sin fraude hubiéramos ganado".

\section{(ब) (ब००}

La Revista Estudios es editada por la Universidad de Costa Rica y se distribuye bajo una Licencia Creative Commons Atribución-NoComercial-CompartirIgual 3.0 Costa Rica. Para más información envíe un mensaje a revistaestudios.eeg@ucr.ac.cr. 


\section{Especial: Profesores de Estudios Generales Investigan}

Para José Figueres la circunstancia del fraude lo llevó a plantear que el gobierno por su origen era ilegítimo y que debía ser derrocado por la vía militar. Desde ese momento, aún en el exilio, José Figueres no reconoció la legitimidad del gobierno de Picado Michalski. Iniciado el Gobierno de Teodoro Picado, José Figueres regresa al país, donde es recibido como un gran líder y se integró a la lucha política, preparándose en lo militar, en sus fincas al sur de la capital.

\section{Hitler estaba siendo derrotado}

En el plano internacional, Hitler venía en retirada. El Ejército Rojo le había frenado y lo estaba haciendo retroceder. Los Pactos, que se firmaban en torno a la II Guerra a su final y a los meses posteriores, daban por un hecho una nueva geografía europea y mundial, eran, entre otros, el Acuerdo Anglo Soviético (el 12 de julio de 1941), el Acuerdo Sikorski-Maiski, de la Unión Soviética con Inglaterra (el 30 de julio de 1941), el Acuerdo Churchill Stalin sobre los Balcanes (a finales de 1944), el Armisticio entre Italia y los aliados (el 3 de setiembre de 1943), la Conferencia de Teheran (el 27 noviembre de 1943), de Stalin, Churchill y Roosevelt, la Conferencia de Dumbaton-Oaks (entre el 21 y el 29 agosto de 1944), en Washington, donde empezó a formularse la creación de las Naciones Unidas, la Conferencia de Yalta (durante los días del 4 al 11 de febrero de 1945), de Stalin, Churchill y Roosevelt, la Declaración de la Europa Liberada (entre el 4 y el 11 de febrero de 1945), el Acuerdo de Postdam (el 3 de agosto de 1945), que impone la división de Alemania, la Rendición de Japón (el 15 de agosto de 1945), la Conferencia de San Francisco, en octubre de 1945 que culminó con la constitución de la ONU, con Costa Rica como uno de sus 50 países fundadores, el Tratado de París (de 10 de febrero de 1947) para tratar de resolver conflictos territoriales y deshacer las fronteras hechas por Hitler. Junto a estos eventos

\section{(C) $(00$}

La Revista Estudios es editada por la Universidad de Costa Rica y se distribuye bajo una Licencia Creative Commons Atribución-NoComercial-CompartirIgual 3.0 Costa Rica. Para más información envíe un mensaje a 
también se produjeron seis Conferencias en Moscú, en 1941, en 1942, dos en 1943, en 1944 y en 1945.

El escenario más impactante fue en Europa donde la geografía política se alteró con el surgimiento de una serie de países socialistas que emergieron al finalizar la guerra, Bulgaria, Polonia, Hungría, Checoslovaquia, Rumania, Albania, Yugoslavia, Estonia, Letonia y Lituania, Alemania Oriental.

Esta situación condujo al rompimiento internacional de los aliados y al desarrollo de la Guerra Fría. Winston Churchill, frente al avance del socialismo, inició su política de rompimiento de la alianza internacional surgida de la lucha contra el fascismo, e inició un nuevo eje de lucha contra el avance comunista internacional, ideó para la Europa la imagen de la Cortina de Hierro y para el Asia, ante el avance de la liberación de los pueblos de China, de las Penínsulas de Indochina y de Corea, y de la lucha anticolonial de la India, ideó la imagen de la Cortina de Bambú, y de aislamiento de esos países.

En Costa Rica inmediatamente repercutió esta nueva política mundial. Otilio Ulate Blanco la abanderó con una campaña virulenta en su periódico de "no le compre, no le venda, no le hable a los comunistas". La lucha anticomunista en el país se exacerbó. Otilio Ulate había estado en Europa, como periodista, cubriendo los últimos acontecimientos, y se trajo a Costa Rica el discurso anticomunista de Churchill.

\section{Otilio Ulate Blanco, líder político de la oposición}

En 1946 muere León Cortés. La dirección política de la oposición la disputan principalmente José Figueres y Otilio Ulate Blanco. José Figueres manteniendo su tesis militarista y Ulate Blanco sosteniendo que había que ir a las elecciones de 1948, afirmando que, si en ellas se volvía a repetir el fraude, entonces aceptaba la solución militar que proponía José Figueres.

\section{(c) (i)(2)}

La Revista Estudios es editada por la Universidad de Costa Rica y se distribuye bajo una Licencia Creative Commons Atribución-NoComercial-CompartirIgual 3.0 Costa Rica. Para más información envíe un mensaje a 


\section{Especial: Profesores de Estudios Generales Investigan}

El gobierno de Picado Michalski se llena de escándalos. Se le acusa de nepotismo, de corrupción. Impulsa en 1946 una Reforma Tributaria bastante buena para la época, y por iniciativa de los comunistas, un Código Electoral, con el fin de dar garantías de que no habría fraudes electorales, en adelante, en los procesos electorales, y se integra el Tribunal Nacional Electoral.

En 1946 la oposición organiza una huelga médica contra la CCSS. El año 1947 se vuelve más tenso. Hay una ola de terrorismo contra objetivos del gobierno y de los comunistas, atentados, bombas a las casas de dirigentes y de los periódicos, atentados contra instalaciones eléctricas. Se organiza, desde finales de julio hasta principios de agosto, la Huelga de Brazos Caídos, con el objetivo de controlar la oposición el aparato electoral y la policía nacional, como garantía hacia las elecciones de 1947-1948. La huelga muy mal atendida por el Gobierno terminó violentamente y el Gobierno se vio obligado a entregar el aparato electoral a control de la oposición política.

En los últimos meses de 1947 el gobierno detiene un joven estudiante acusado de terrorismo, capturado in fraganti, poniendo una bomba. Para la oposición era una víctima inocente y un pretexto del gobierno. El joven Federico Apéstegui se convirtió en el tema de discusión de estas tesis.

Frente al terrorismo impuesto por la oposición, el Partido Vanguardia Popular, que era parte de sus objetivos y víctima de ese terrorismo, desarrolló las "Brigadas de Choque" poniéndole más tensión al ambiente político nacional, por los enfrentamientos de calle que se producían. El Gobierno por su parte usando la policía, jefeada por Juan José Tavío y Silva, figura tenebrosa de origen cubano, reprimía violentamente a los opositores, y cuando podía también a los comunistas. Hacia las elecciones de 1948 el gobierno impulsa la candidatura del Dr. Calderón Guardia. La oposición impulsa a Otilio Ulate Blanco. Los comunistas habían propuesto candidato propio hasta diciembre de 1947, porque no estaban de acuerdo con la candidatura de Calderón Guardia. En diciembre los comunistas

\section{(c) (i) (-)}

La Revista Estudios es editada por la Universidad de Costa Rica y se distribuye bajo una Licencia Creative Commons Atribución-NoComercial-CompartirIgual 3.0 Costa Rica. Para más información envíe un mensaje a 


\section{Especial: Profesores de Estudios Generales Investigan}

retiran su candidato para apoyar, a la fuerza, a Rafael Ángel Calderón Guardia, y sin pacto entre partidos, ante la tensión existente y temiendo que se pusieran en riesgo las Garantías Sociales y el Código de Trabajo.

La candidatura de Calderón Guardia era más presionada por su segunda esposa, doña María del Rosario Fournier Mora, que le exigía que quería ser Primera Dama, en una situación en la cual el Dr. Calderón Guardia estuvo casi a punto de retirarse de la contienda electoral.

José Figueres, por su parte, en ese final de 1947 y hasta las elecciones estaba atrincherado en sus fincas, en La Lucha, preparándose militarmente.

\section{Figueres y La Legión Caribe}

La estancia en México le había llevado a vincularse a una serie de personajes de Centroamérica y del Caribe, demócratas, que luchaban contra las dictaduras existentes en sus países, la dictadura de Jorge Ubico en Guatemala, desde 1931 hasta 1944, cuando se desarrolló la Revolución Democrática de Octubre, que llevó a los gobiernos a Juan José Arévalo Bermejo y a Jacobo Arbenz Guzmán, las dictaduras de Maximiliano Hernández Martínez en el Salvador hasta 1944, la de Tiburcio Carías Andino, en Honduras, desde 1932 hasta su muerte en 1948, la de Anastasio Somoza García, en Nicaragua, desde 1937 hasta 1978, la de Rafael Leónidas Trujillo, en República Dominicana, desde 1930 hasta 1961.

Este grupo de exiliados interesados en restaurar democracias en sus países, termina fundando la llamada Legión del Caribe, primero como una convergencia de luchadores sociales y políticos, luego como una organización militar en posibilidad de desarrollar luchas armadas contra estas dictaduras y restablecer regímenes democráticos.

José Figueres les vendió la idea de que había que derrocar primero a Teodoro Picado Michalski, porque su gobierno era ilegítimo, resultado de un fraude y 


\section{Especial: Profesores de Estudios Generales Investigan}

porque además, tenía el Ejército más débil de la región, y que una vez que fuera derrocado Teodoro Picado Michalski, seguían, desde Costa Rica, hacia arriba, derrocando a Anastasio Somoza y a las otras dictaduras.

El 17 de diciembre de 1947, en Guatemala, firmaron el Pacto del Caribe, nicaragüenses, dominicanos y costarricenses, con José Figueres, y con apoyo del Presidente Jacobo Arbenz.

En el Pacto del Caribe se señala que son un equipo revolucionario para derrocar dictaduras y que para la ejecución de su Plan de Liberación, en cada país se organizará una Junta de Gobierno. Igualmente, señalan que al tomar el poder convocarán inmediatamente a la redacción de una nueva Constitución Política. Así José Figueres desde diciembre de 1947 ya estaba pensando en la posibilidad de impulsar su Junta de Gobierno y de impulsar una nueva Constitución. Así, también, en el Pacto del Caribe estaba implícita la idea de la Asamblea Nacional Constituyente que luego José Figueres convoca, ya en el Poder.

\section{Las elecciones de 1948}

El 8 de febrero de 1948 se producen las elecciones, en un ambiente muy tenso, con un aparato electoral en manos de la oposición, con un aparato policial represivo fuerte por parte del gobierno. El gobierno con su aliado a la fuerza en esa etapa final, el Partido Vanguardia Popular y sus organizaciones sociales y sindicales, junto con la Iglesia. La oposición con el Partido Unión Nacional, reunía el apoyo de varios grupos de partidos, que venían desde las elecciones de 1944, el Demócrata, el Unión Nacional y el Social Demócrata, además con el apoyo de la Confederación Costarricense de Trabajadores Rerum Novarum, que dirigían el padre Núñez y Luis Alberto Monge.

El resultado electoral sale beneficiando a Otilio Ulate Blanco a la presidencia con 54.931 (56.3\%) votos y al gobierno con 44.438 (44.7\%) de votos.

\section{(C) $(0 \bigcirc)$}

La Revista Estudios es editada por la Universidad de Costa Rica y se distribuye bajo una Licencia Creative Commons Atribución-NoComercial-CompartirIgual 3.0 Costa Rica. Para más información envíe un mensaje a revistaestudios.eeg@ucr.ac.cr. 


\section{Especial: Profesores de Estudios Generales Investigan}

Para los comunistas y el gobierno, en las elecciones estaban en juego la continuidad de las Garantías sociales y el Código de Trabajo, para la oposición el respeto y la libertad de sufragio.

El 28 de febrero el Tribunal Nacional Electoral dio oficialmente el fallo, señalando a Ulate Blanco como ganador, con un voto salvado, en el cual se señalaban inconsistencias en el proceso electoral. En la época, de acuerdo a la legislación y Constitución Política, los resultados se pasaban al Congreso, quien tenía la potestad de avalar o no sus resultados, para su ratificación.

Con una mayoría de diputados de gobierno y de diputados comunistas, el Congreso se pronunció anulando las elecciones presidenciales, favorables a Otilio Ulate Blanco y avalando las elecciones de diputados donde los comunistas y los gobiernistas habían aumentado su número. En contra de la nulidad estaban los diputados José Albertazzi Avendaño, jefe de la bancada parlamentaria oficialista y Manuel Mora Valverde, jefe de los diputados comunistas.

Rafael Ángel y Francisco Calderón Guardia se reúnen con Manuel Mora y José Albertazzi, en la casa de José Albertazzi Avendaño, para discutir la nulidad. Rafael Ángel Calderón G. insistió en que se debía anular la elección. De una reunión muy tensa resultó el acuerdo de la nulidad que aprobaron los respectivos partidos para proceder en el Congreso a la nulidad, como lo había impuesto Calderón Guardia. En el Partido Vanguardia Popular, Jaime Cerdas Mora y Manuel Moscoa, también se opusieron a la nulidad. Se hizo la votación.

Votaron 27 diputados por la nulidad y 19 en contra. Ese fue el resultado. A favor de la nulidad votaron José Albertazzi Avendaño, Vidal Arguedas Quirós, Virgilio Calvo Brenes, Luis Carballo Corrales, Gilberto Charpentier, Filiberto Chavarría, Manuel Mora Valverde, Federico Volio, Emilio Sanahuja, Antonio Riggioni Rubillo, José Saborío Alfaro, Onofre Villalobos Soto, José Fernández Ferreiro, Alfredo Picado, Luis Calvo Gómez, Francisco Quesada, Víctor

\section{(c) (i) (2)}

La Revista Estudios es editada por la Universidad de Costa Rica y se distribuye bajo una Licencia Creative Commons Atribución-NoComercial-CompartirIgual 3.0 Costa Rica. Para más información envíe un mensaje a revistaestudios.eeg@ucr.ac.cr. 
Especial: Profesores de Estudios Generales Investigan

Rodríguez, Enrique Baltodano, Juan Muñoz Rovira, Rodolfo Salazar, Efigenio Vallejo, Carlos Barahona, Carlos Luis Fallas Sibaja, Francisco Quintana, Luis Vasco Soto, Jaime Cerdas y Alvaro Cubillo Aguilar.

En contra de la nulidad votaron Francisco Fonseca Chamier, Juan José Herrero, Fernando Lara Bustamante, Antonio Peña Chavarría, Tomás Guardia Tinoco, Otto Cortés Fernández, Antonio Chaves Soto, Francisco José Orlich Bolmarcich, Marcial Rodríguez Conejo, Luis Carlos Suarez, Rodrigo Valverde, Adriano Camacho, Jorge Ortiz Martín, Fernando Volio Sancho, Bernardo Benavides Zumbado, Víctor Manuel Elizondo, Rubén González Flores, Eladio Rosabal Cordero y Arturo Volio Guardia.

\section{El alzamiento militar de Figueres y la guerra civil}

El acto de nulidad provocó el alzamiento militar de José Figueres iniciando el 12 de marzo la llamada Guerra Civil de 1948, que se prolongó hasta el 17 de abril de 1948.

Desde el primer día de su alzamiento militar José Figueres recibió apoyo de la Legión Caribe, luego de que, en la acción de la toma de San Isidro de El General, lograron capturar un avión y con una maniobra, con la que engañaron al Gobierno, lograron hacerse de un segundo avión, que los enviaron a Guatemala para recibir el apoyo logístico militar para su movimiento rebelde.

El desarrollo del conflicto militar le fue dando ventaja a José Figueres y su llamado Ejército de Liberación Nacional. Los comunistas, que eran el principal soporte militar no recibían por parte del gobierno el apoyo suficiente y lo acusaban de sabotear la defensa que se hacía. En el seno del gobierno había temor en algunos sectores, entre ellos el que encabezaba el hermano del Presidente Picado, de que los comunistas con las armas se pudieran quedar también con el gobierno.

\section{(c) (i) (2) (2)}

La Revista Estudios es editada por la Universidad de Costa Rica y se distribuye bajo una Licencia Creative Commons Atribución-NoComercial-CompartirIgual 3.0 Costa Rica. Para más información envíe un mensaje a revistaestudios.eeg@ucr.ac.cr. 


\section{Especial: Profesores de Estudios Generales Investigan}

A mediados de abril prácticamente José Figueres dominaba todo el territorio. Ya se encontraba en Cartago. En Tres Ríos, el dirigente comunista y miembro del Estado Mayor, Carlos Luis Fallas, aseguraba tener 7000 hombres listos para combatir y aplastar a José Figueres, pero exigía las armas y los pertrechos que el gobierno se negaba a darle.

La Batalla de San José, como se le llamó, se presagió como la más sangrienta. Ante esta situación se actuó con la intención de evitarla. Ello significaba reconocer el triunfo militar de José Figueres. Con ese propósito se movieron actores que convocaron a José Figueres y a Manuel Mora a reunirse en Ochomogo, a mitad del escenario de guerra, entre Cartago y San José.

El Gobierno de Teodoro Picado Michalski constitucionalmente duraba desde el 8 de mayo de 1944 hasta el 8 de mayo de 1948, cuando debía entregar el Gobierno al nuevo presidente, surgido de las elecciones de febrero de 1948, en este caso a Otilio Ulate Blanco.

Al anularse la elección presidencial, José Figueres se levantó en armas, bajo el pretexto de respetar el resultado electoral y entregarle el gobierno, que no se le quería reconocer, a Ulate Blanco.

En el desarrollo del conflicto militar José Figueres considera la posibilidad de quedarse gobernando, antes de entregarle el Gobierno a Otilio Ulate Blanco.

En la Primera Proclama de Santa María de Dota, al calor de la guerra, el 23 de marzo, José Figueres dice: "Fundaremos la Segunda República. El 1 de abril, de nuevo, desde Santa María de Dota, en la Segunda Proclama, además de enfatizar en asuntos sociales, declara contundentemente que el Ejército de Liberación Nacional, que él lidera, tiene por misión "fundar la Segunda República", para iniciar "la guerra contra la pobreza". "La Victoria del Ejército de Liberación Nacional será la Segunda República, y la Victoria de la Segunda República será el bienestar del mayor número".

\section{(ब) $(\Theta \odot$}

La Revista Estudios es editada por la Universidad de Costa Rica y se distribuye bajo una Licencia Creative Commons Atribución-NoComercial-CompartirIgual 3.0 Costa Rica. Para más información envíe un mensaje a 


\section{Especial: Profesores de Estudios Generales Investigan}

El 13 de abril de 1948, desde Cartago, en documento firmado, José Figueres, Alberto Martén Chavarría y Fernando Valverde Vega, se dirigen al Presidente Picado Michalski y a sus tres Designados a la Presidencia, pidiéndoles las renuncias de sus cargos y proponiendo que ante tales renuncias, el Congreso nombre como Designados a la Presidencia, lo cual era potestad del Congreso, en su orden a José Figueres, Alberto Martén y Fernando Valverde, de manera que el Primer Designado, José Figueres, pasara a ejercer la Presidencia de la República y recibir la entrega de todas las fuerzas armadas del gobierno. Proponía José Figueres entre otros extremos, amnistía general, respeto de vidas y haciendas, asilo diplomático, y declarar una tregua general.

El Presidente Teodoro Picado Michalski al recibir la propuesta, en esa misma fecha, 13 de abril, hace un Memorandum, donde señala que varios miembros del Cuerpo Diplomático han estado interviniendo para "mediar en la presente guerra civil" y para "encontrar una solución patriótica evitando que se derrame más sangre". Considera en su Memorandum que las personas propuestas "no son prenda de paz para la familia costarricense" y que "por el contrario se envenenaría la extraordinaria agitación pasional que sufre la República", y que las "Designaturas no podrían por el breve tiempo que ejercerían desarrollar la política de fraternal armonía que el país requiere", que eso "sería de consecuencias imprevisibles y de peligrosas resultancias". Señala que se niega a renunciar ante los pocos días que le faltan para terminar su mandato presidencial. Por ese motivo valora dejar la Presidencia en el Designado Santos León Herrera, persona en capacidad de "avalar la paz del país", "suavizar las asperezas de la enconada contienda".

El Presidente Teodoro Picado Michalski, ante esa propuesta de José Figueres, no renuncia, ni renuncian sus Designados a la Presidencia. Inmediatamente, el 14 de abril, al día siguiente le dirige una carta al Designado a la Presidencia, Santos León Herrera, indicándole que el Padre Benjamín Núñez y Francisco Calderón

\section{(c) (i) (9) (2)}

La Revista Estudios es editada por la Universidad de Costa Rica y se distribuye bajo una Licencia Creative Commons Atribución-NoComercial-CompartirIgual 3.0 Costa Rica. Para más información envíe un mensaje a 


\section{Especial: Profesores de Estudios Generales Investigan}

Guardia, que han estado en esas conversaciones para ponerle fin a la guerra, le explicarán el "sacrificio que el país le exige por las gravísimas circunstancias que lo ameritan". En esa misma nota Picado Michalski le dice que el Cuerpo Diplomático intervendrá para darle respaldo moral a lo que está proponiendo.

\section{El contexto regional influye en el final de la guerra civil}

En estos días finales de la guerra se habían producido dos sucesos que afectaban al país, en el escenario de la guerra interna. El asesinato de Jorge Eliécer Gaitán Ayala, el 9 de abril de 1948, provocando con su muerte un levantamiento popular en Colombia, que alteraba según el General George Marshall, de los Estados Unidos, que estaba de visita en Colombia, la seguridad del Canal de Panamá. Igualmente, señalaba que el conflicto generado en Costa Rica también alteraba la seguridad del Canal. Declaró, también que no se movía de la región hasta que no se tranquilizara la situación alrededor del Canal, dando órdenes de movilizar tropas hacia Costa Rica.

Anastasio Somoza García, por su parte, preocupado por el avance y el triunfo de José Figueres, se mueve en igual sentido ante el Presidente Picado Michalski. Le propone que siendo aliados los gobiernos y amistosos, como lo han sido, se traslade a Liberia, que establezca el Gobierno en Liberia, que una vez establecido en Liberia le pida ayuda militar para combatir a José Figueres, y hecha esa solicitud, él, Somoza, entra a enfrentar a José Figueres, a liquidarlo y que de paso barre también con los comunistas. Esto no lo aprueba Picado Michalski y le dirige una carta a Rafael Ángel Calderón Guardia y a Manuel Mora Valverde donde les explica esta situación que lo obliga a dejar el Gobierno, para evitar una mayor tragedia.

Ante esta amenaza externa Manuel Mora Valverde consideraba que se debía actuar conjuntamente con José Figueres para enfrentar la movilización del 


\section{Especial: Profesores de Estudios Generales Investigan}

General Marshall y la amenaza de Anastasio Somoza, que llegó a intervenir en el norte con su Ejército, más como una advertencia a José Figueres. Así Manuel Mora Valverde se lo planteó a José Figueres en Ochomogo y José Figueres le manifestó que la forma, para evitar esa posibilidad, era que los comunistas se desarmaran y él se encargaría de la situación, ya que no podía convencer a su tropa de pelear al lado de los comunistas aún contra esa amenaza extranjera.

\section{La conversación de Ochomogo}

El 17 de abril, por la noche, se encontraron en Ochomogo Manuel Mora Valverde y José Figueres, quienes se habían hecho acompañar de Carlos Luis Fallas y Benjamín Núñez. La conversación realizada se conoce como el Pacto de Ochomogo.

Allí, mientras José Figueres y Manuel Mora se ponían de acuerdo, al final, se oyó una voz desde un matorral que dijo: "Y que se agregue en el documento el respeto por las Garantías Sociales". Figueres, desenfundó un arma que llevaba y dijo: “¿Quién está ahí? Carlos Luis Fallas respondió: "Yo, Carlos Luis Fallas”. “¿Y por qué viene armado?", inquirió Figueres. "Para defender a Manuel si fuera necesario", respondió Fallas. "Y, usted, ¿por qué viene armado, si se dijo que debían venir sin armas?", preguntó Fallas, a lo cual Figueres le respondió: "Vengo armado porque si alguno de mis soldados intentara matar a Manuel, yo le mato". Inmediatamente se instruyó al Padre Benjamín Núñez, para que por escrito recogiera lo hablado. Así el 19 de abril de 1948 el padre Núñez dirigió una nota a Manuel Mora Valverde, resumiendo el contenido de la conversación de Ochomogo y destacando que ese encuentro había sido promovido por el Presidente Picado Michalski, para "dar fin a la guerra", y que en el Gobierno que dirigirá Santos León Herrera se le integrará a él y a Miguel Brenes en las Secretarías de Seguridad Pública y de Trabajo.

\section{(C) $(\Theta \odot$}

La Revista Estudios es editada por la Universidad de Costa Rica y se distribuye bajo una Licencia Creative Commons Atribución-NoComercial-CompartirIgual 3.0 Costa Rica. Para más información envíe un mensaje a revistaestudios.eeg@ucr.ac.cr. 


\section{Especial: Profesores de Estudios Generales Investigan}

En esta nota el Padre Núñez señala que tienen el propósito de "revolucionar las formas de vida del país mediante la promulgación de una Constitución moderna". Aquí está clara la idea de que no entregarán el Gobierno a Otilio Ulate Blanco y de que convocarán una Asamblea Nacional Constituyente. Decía el Padre Núñez que querían que en la Asamblea Constituyente participaran los comunistas.

Añadía a la Carta "el Pliego de garantías" acordado en Ochomogo, como "parte de su programa social de gobierno": respeto de las garantías sociales, respeto sin modificaciones del Código de Trabajo, libertad de organización de la clase trabajadora, respeto de las garantías sindicales, apoyo a las centrales sindicales, respetar y restructurar el sistema de seguridad social y de riesgos profesionales, ejecutar un plan de viviendas, asegurar la alimentación de la población, respeto absoluto al sistema democrático republicano, respeto de las libertades y de organización de todos los partidos, darle más bases técnicas al impuesto sobre la renta, distribución de tierras, indemnizaciones para todas las familias y víctimas de la guerra civil.

\section{José Figueres anuncia la Segunda República}

Suspendidas las acciones militares, asumido el Gobierno por el Ingeniero Santos León Herrera, para terminar el mandato constitucional de Teodoro Picado Michalski, se preparó la entrada de José Figueres de Cartago a San José.

El 28 de abril de 1948 entró victorioso José Figueres a la capital, sin poder asumir el Gobierno, porque estaba finalizando constitucionalmente el Gobierno de Teodoro Picado Michalski, en manos de su Designado a la Presidencia, Santos León Herrera.

En el Desfile de la Victoria José Figueres, principal líder de la guerra civil, hizo el discurso principal.

\section{(a) $\mathbb{Q} \Theta($}

La Revista Estudios es editada por la Universidad de Costa Rica y se distribuye bajo una Licencia Creative Commons Atribución-NoComercial-CompartirIgual 3.0 Costa Rica. Para más información envíe un mensaje a 


\section{Especial: Profesores de Estudios Generales Investigan}

Señaló que: "las armas habían dado la victoria; pero que las leyes darían la libertad". Veía a Otilio Ulate Blanco como "un manto protector sobre la Patria". "La presencia de don Otilio Ulate Blanco, dijo, representa en este momento, para los costarricenses, una doble garantía: primera, porque él, es un digno representante de la República de don Cleto, de la Primera República. Segundo, porque su juventud física y mental y su cultura, son una promesa de que en este momento de honda transformación nacional, no van a detener lo inatajable en Costa Rica y en el mundo: el carro del progreso."

Señaló el establecimiento de la Segunda República a fundar. Dijo: "En primer lugar nosotros debemos ver que no se sacrifique nada, en la Segunda República, de lo mucho bueno que tuvo la primera." Y enfatizó: "que no se sacrifique nada, en la Segunda República, de lo mucho bueno que tuvo la primera. Muy en especial debemos heredar dos joyas preciosas, que fueron pulidas con paciencia y con el tiempo mediante el trabajo sapientísimo de varones ilustres. Ambas joyas son de igual valor, aunque se menciona más a menudo una que la otra. Me refiero, costarricenses, al derecho del sufragio electoral y a la independencia del Poder Judicial. Esas dos prendas tienen entre si la relación curiosa, de que cuando un país se degenera, la del sufragio es la primera que se pierde. La otra, la majestad de la justicia, tras un largo proceso de derrumbe de valores, viene a ser la última perdida".

Enfatizó, igualmente, "la reconstrucción nacional que ha de conducir a la fundación de la Segunda República”.

No hay nada textual que justifique el nombre de la Segunda República, como llamará José Figueres su Gobierno de Facto. Dos razones debieron pesar. La primera, el centenario, 1848 -1948, de la proclamación de la República por el Dr. José María Castro Madriz. La segunda: para José Figueres los ocho años de gobiernos de Calderón Guardia y Picado Michalski habían acabado con la República por la corrupción, el nepotismo, los abusos, los fraudes electorales, la 
Especial: Profesores de Estudios Generales Investigan

represión y persecución policial que se realizaba. Por eso había necesidad de fundar una nueva República, la Segunda, la que tendría también su Constitución Política.

Ya en San José Figueres, desde el 28 de abril, se impuso sobre Otilio Ulate Blanco, le obligó a firmar el llamado "Pacto Ulate Figueres", el 1 de mayo de 1948, ocho días antes de asumir la Presidencia de manos de Santos León Herrera.

En este Pacto José Figueres reconoce que Otilio Ulate Blanco fue el último presidente constitucionalmente electo en Costa Rica, el 8 de febrero de 1948, que asumirá el Gobierno que se instalará bajo la modalidad de una Junta Revolucionaria, como se decía en el Pacto del Caribe, que gobernará el país por 18 meses, prorrogables a 24 si fuere necesario y que se convocará a elecciones para integrar una Asamblea Constituyente.

De esta manera al negarle la entrega inmediata de la Presidencia a Otilio Ulate Blanco, José Figueres dio un Golpe de Estado contra el Presidente electo, e inició su Gobierno de Facto, de dictadura, de gobierno inconstitucional, por cuanto suspendió la Constitución vigente, la de 1871 y empezó a gobernar mediante Decretos Leyes, e inició una serie de medidas persecutorias contra los opositores políticos y miembros de los partidos Republicano y Vanguardia Popular, y de las organizaciones populares y sindicales influidas por esos partidos, así como contra funcionarios de los gobiernos anteriores.

Pocas semanas después de asumir el Gobierno, José Figueres, por el Decreto Ley No. 77, desconoció lo acordado en Ochomogo y en la Embajada de México, para poder llevar a cabo ampliamente su represión y autoritarismo político y militar. Para ello adujo que el Gobierno de Teodoro Picado Michalski no dio cumplimiento a las obligaciones contraídas, que las hostilidades no cesaron, que ellos, los de la Junta de Gobierno, sí habían cumplido, por lo que declaran resuelto el pacto firmado.

\section{(c) (†) (-)}

La Revista Estudios es editada por la Universidad de Costa Rica y se distribuye bajo una Licencia Creative Commons Atribución-NoComercial-CompartirIgual 3.0 Costa Rica. Para más información envíe un mensaje a revistaestudios.eeg@ucr.ac.cr. 


\section{Especial: Profesores de Estudios Generales Investigan}

El autoritarismo ya había empezado a funcionar desde que José Figueres asumió el 8 de mayo de 1948 el Gobierno por la fuerza. La dictadura del Gobierno de Facto se desarrolló desde el mismo 8 de mayo de 1948 hasta el 7 el noviembre de 1949, fecha en que cesó sus funciones la Asamblea Nacional Constituyente, cuando se dio por aprobada al Constitución Política actual, que entró en vigencia el 8 de noviembre, cuando cesa la Junta Fundadora de la Segunda República y se restaura el ejercicio de gobiernos constitucionalmente electos, entregándole la Presidencia a Otilio Ulate Blanco y haciendo que en esa misma fecha funcione el Poder Legislativo, también electo popularmente, aunque con restricciones de participación bajo la Junta de Gobierno. Se restaura el régimen y el sistema democrático, y la democracia política, representativa.

Durante la Junta Fundadora de la Segunda República se hicieron acciones de gobierno importantes, mediante los Decretos Leyes que realizó, gobernando sin Congreso. Entre estas acciones estuvieron la nacionalización bancaria, impuso un impuesto del $10 \%$ al capital, nacionalizó los recursos hidroenergéticos, el respeto al Código de Trabajo que se había aprobado en 1943, a pesar de que tenía otro Código de Trabajo como proyecto, que no pudo aprobar y mantuvo las Garantías Sociales, establecidas en el Constitución, en 1943, que fueron ligeramente ampliadas en la Constitución Política de 1949. Convocó a elecciones de una Asamblea Nacional Constituyente, que operó durante el año de 1949 redactando la actual Constitución Política de Costa Rica que cumple en noviembre 70 años, abolió el Ejército como institución permanente, en la Constitución Política de 1949, aunque en diciembre de 1948 se hizo una ceremonia en el Cuartel Bellavista, en la cual entregó el Cuartel a la Universidad de Costa Rica para hacer un Museo. En esa ocasión derribó una almena del Cuartel, simbólicamente, evento al que se ha atribuido que es el momento en que se abolió el Ejército Nacional y así se celebra, cuando aún ni siquiera se había instalado la Asamblea Nacional Constituyente.

\section{(c) (1) (2)}

La Revista Estudios es editada por la Universidad de Costa Rica y se distribuye bajo una Licencia Creative Commons Atribución-NoComercial-CompartirIgual 3.0 Costa Rica. Para más información envíe un mensaje a 
Especial: Profesores de Estudios Generales Investigan

En su gobierno se proscribió el Partido Comunista, situación de ilegalidad que se prolongó hasta 1974-1975, en que se eliminaron las restricciones legales y constitucionales que le prohibían.

\section{La Asamblea Nacional Constituyente}

La convocatoria de la Asamblea Nacional Constituyente se hizo en diciembre para que empezara sus funciones el 15 de enero de 1949.

La Asamblea Nacional Constituyente se integró con representantes de cuatro partidos políticos, 34 diputados del Partido Unión Nacional, que respondían a Ulate Blanco, o el ulatismo, 6 del Partido Constitucional, 4 del Partido Social Demócrata, que respondían a los intereses del movimiento político militar de José Figueres y uno del Partido Confraternidad Nacional.

El resultado electoral para la integración de la Asamblea Nacional Constituyente fue un fuerte rechazo a José Figueres y su movimiento armado, pero fue también una protesta política popular por no haber entregado la Presidencia inmediatamente a Otilio Ulate Blanco. Solo así puede interpretarse el número reducido de diputados que sacó José Figueres, aunque todos ellos brillantes y muy influyentes en las deliberaciones de la Asamblea Constituyente. José Figueres en ese momento tenía el apoyo sostenido por las armas y la fuerza de su Gobierno dictatorial. Evidentemente las elecciones le demostraron que no tenía apoyo popular, expresado en elecciones.

Igual sucedió cuando la Junta de Gobierno entrega un Proyecto de Constitución Política, para que se tenga como base de discusión para redactar la nueva, y le fue rechazado. De nuevo, ahora los Diputados Constituyentes electos rechazaron a la Junta Fundadora de la Segunda República y a José Figueres, más allá de que el Proyecto de Constitución hubiera sido redactado por importantes juristas y algunos diputados electos a la Constituyente.

\section{(c) (i) (2) (2)}

La Revista Estudios es editada por la Universidad de Costa Rica y se distribuye bajo una Licencia Creative Commons Atribución-NoComercial-CompartirIgual 3.0 Costa Rica. Para más información envíe un mensaje a 


\section{Especial: Profesores de Estudios Generales Investigan}

El Proyecto de Constitución presentado por la Junta Fundadora de la Segunda República se proponía sustituir el "régimen personalista" o presidencialista que venía operando con la Constitución de 1871, por "uno institucional", que "mantuviera la unidad del Estado pero descentralizando". Planteaba la igualdad de derechos políticos para hombres y mujeres, se pronunciaba por crear "un sólido órgano electoral, independiente, que garantice la pureza del sufragio", señalaba supresión del Ejército, proponía una "mayor independencia del régimen municipal". Fue un Proyecto de Constitución tan extenso y reglamentario como las Constituciones de 1871 y 1917. Proponía "resguardar la libertad y dignidad del individuo frente a las funciones del Estado". En materia de nacionalidad se apartaban del principio de "ius solis" de los nacidos de padres extranjeros en territorio nacional, dejándole la "resolución sobre nacionalidad al Registro Civil". Integró a los guanacastecos registralmente respecto a la nacionalidad costarricense. En materia de Derechos Políticos la Junta Fundadora de la Segunda República propuso el voto a los 18 años "sin excepciones", la "prohibición de que las deudas políticas se paguen con las remuneraciones de los servidores públicos", por "ayuda del Estado para contribuir a los gastos de propaganda electoral". Señala al Tribunal Supremo de Elecciones como "la entidad rectora de todas las actividades del sufragio", con "facultad soberana de efectuar el escrutinio definitivo,... con decisiones inapelables y definitivas". Eliminaron la intervención de los Poderes Públicos para nombrar a los magistrados electorales. Incorporaron el juicio contencioso administrativo en manos del Poder Judicial. Propuso integrar la Corte Suprema de Justicia con 17 Magistrados propietarios inamovibles y 25 magistrados suplentes, de período fijo, "elegidos libremente por la Asamblea Legislativa" de "la lista que envía la Corte en número doble al que debe elegirse", indicando que los "magistrados debían tener 35 años de edad y 10 de ejercicio profesional del Derecho", con obligación de "retiro a los 70 años".

\section{(c) (i) (-)}

La Revista Estudios es editada por la Universidad de Costa Rica y se distribuye bajo una Licencia Creative Commons Atribución-NoComercial-CompartirIgual 3.0 Costa Rica. Para más información envíe un mensaje a 


\section{Especial: Profesores de Estudios Generales Investigan}

En materia legislativa Junta Fundadora de la Segunda República propuso cambiar el nombre de Congreso Constitucional por Asamblea Legislativa. Cambiaron el sistema de elección provincial por el nacional de diputados. No estuvieron de acuerdo con la reelección de diputados pero si con la renovación parcial, cada dos años, de los diputados "ya que en esa forma se practica una consulta popular sobre la gestión política y administrativa del Gobierno". Establecieron también las sesiones ordinarias y extraordinarias de la Asamblea, como está establecido hoy. Establecían la facultad de los diputados de "dar votos de censura contra los Ministros del Gobierno".

Establecieron en el Proyecto de Constitución el capítulo especial relacionado con el Presupuesto de la República, y los principios constitucionales que lo deben regir, como "el de unidad del presupuesto", el de "prohibir la reducción de las remuneraciones de los servidores públicos" y de un sistema "obligatorio de licitaciones públicas". La junta también propuso constitucionalmente la Contraloría General de la República.

En materia del Poder Ejecutivo la Junta Fundadora de la Segunda República propuso la elección de los Vicepresidentes conjuntamente con la del Presidente, abstrayéndole esa función a la Asamblea Legislativa, como existía anteriormente. Propuso mayor independencia del régimen municipal, el régimen de instituciones autónomas y el Servicio Civil, prohibiendo totalmente "la huelga de los servidores públicos" y de realizar "actividades electorales o de política militante en horas de trabajo".

En el Proyecto de Constitución Política, en su artículo 87 establecieron la prohibición de los "sindicatos de ejercitar actividades de carácter político electoral o religiosas", el Derecho de Huelga excepto en servidores públicos, prohibiendo "el ejercicio de la violencia o la coacción como medio de impulsar, mantener o paralizar el movimiento de huelga".

\section{(a) $\mathbb{Q} \Theta($}

La Revista Estudios es editada por la Universidad de Costa Rica y se distribuye bajo una Licencia Creative Commons Atribución-NoComercial-CompartirIgual 3.0 Costa Rica. Para más información envíe un mensaje a revistaestudios.eeg@ucr.ac.cr. 


\section{Especial: Profesores de Estudios Generales Investigan}

En materia de Derechos políticos la Junta Fundadora de la Segunda República estableció la prohibición, en su propuesta de Constitución, en su artículo 121, que se llevó al segundo párrafo de la Constitución Política aprobada el 7 de noviembre de 1949, de los partidos "que por sus programas, medios de acción, vinculaciones o antecedentes, se opongan al régimen de gobierno representativo democrático de la República, o que atenten contra la soberanía nacional, todo a juicio del Tribunal Supremo de Elecciones". En materia de Magistrados de este Tribunal, la Junta Fundadora de la Segunda República propuso que fueran electos por 10 años.

También sucedió cuando la Junta Fundadora de la Segunda República quiso impulsar un nuevo Código de Trabajo que no se tramitó para su aprobación.

También el pueblo rechazó a Figueres y a la Junta de Gobierno, en las elecciones del 2 de octubre para elegir los diputados del Poder Legislativo que acompañaría al Presidente Otilio Ulate. También se eligieron los vicepresidentes que acompañarían a Ulate, así como las nuevas autoridades de los gobiernos locales.

En estas elecciones el Partido Social Demócrata apenas pudo elegir dos diputados, tres menos de los que había electo para la Asamblea Nacional Constituyente. José Figueres, su Junta de Gobierno y lo que él representaba, era ampliamente rechazado, en ese momento, por la ciudadanía.

\section{La historia constitucional del país era rica}

Hasta la Constitución de 1917 prácticamente el país había tenido 13 Constituciones Políticas. Todas ellas habían ido aportando al enriquecimiento del régimen democrático republicano y constitucional que teníamos. Desde 1824 se había establecido la separación e independencia de los Poderes Públicos, desde esa época se garantizó que cada uno de estos poderes tuviera su especificidad de función y que ella fuera indelegable e insubrogable. En todas ellas se había ido

\section{(c) (i) (9)}

La Revista Estudios es editada por la Universidad de Costa Rica y se distribuye bajo una Licencia Creative Commons Atribución-NoComercial-CompartirIgual 3.0 Costa Rica. Para más información envíe un mensaje a revistaestudios.eeg@ucr.ac.cr. 


\section{Especial: Profesores de Estudios Generales Investigan}

construyendo un conjunto de Libertades y Derechos ciudadanos, enriquecidas con la abolición de la pena de muerte, desde 1878 en que se desaplica y 1882 cuando se proclama la inviolabilidad de la vida, las Garantías Sociales que se incorporaron a la normativa constitucional en 1943, el intento, en la Constitución Política de 1917, de impulsar, con el Artículo 10, políticas de seguridad social.

\section{Las Constituciones son un Programa Político}

Todas las Constituciones constituyeron un Programa político de anhelos y propósitos de la sociedad costarricense, de su convivencia ciudadana, y todas iban expresando particularmente, en el momento en que fueron aprobadas o puestas en vigencia, el desarrollo de la estructura estatal y de la organización político administrativa del Estado y la sociedad costarricense.

Del mismo modo, todas las constituciones fueron configurando los principales valores políticos, ideológicos, espirituales, electorales, ciudadanos y las libertades básicas reconocidas. En todas las Constituciones se afirmó la Independencia y la Soberanía Popular.

En todas las Constituciones se han señalado reconocimientos al papel que ha tenido la religión en la nacionalidad costarricense, y aspectos de relación de la Iglesia con el Estado. Así fue señalado desde la Constitución del 1 de diciembre de 1821, la del Pacto de Concordia, heredando de las Constituciones de Bayona, de 1808, bajo la ocupación francesa de España, y de Cádiz, de 1812, ambas españolas, que habían establecido ese reconocimiento de la religión católica como religión del Estado.

En todas las Constituciones se ha señalado la condición de costarricenses, de nacionalidad, de cómo se adquiere o pierde la nacionalidad, de naturalización, de los derechos de los ciudadanos y de los habitantes, de abolición de la esclavitud, de exaltación de las libertades y derechos. La Constitución de 1844 llegó a

\section{(C) $\odot \Theta \odot$}

La Revista Estudios es editada por la Universidad de Costa Rica y se distribuye bajo una Licencia Creative Commons Atribución-NoComercial-CompartirIgual 3.0 Costa Rica. Para más información envíe un mensaje a revistaestudios.eeg@ucr.ac.cr. 


\section{Especial: Profesores de Estudios Generales Investigan}

establecer un derecho de alterar o cambiar o abolir el gobierno si no llena el objetivo de su institución.

En materia de gobierno todas las Constituciones señalaron la estructura de los poderes públicos, sus funciones y quiénes y cómo podían integrarlos. En este sentido establecieron plazos de gobierno, nunca mayores de 6 años, pero sí reelegibles, incluso sin plazo.

Como objetivo supremo de gobierno en general se ha establecido que lo que se procura es la felicidad y el bienestar de la sociedad y de todos los individuos que la componen. Pocas veces se estableció el sistema bicameral a nivel legislativo. La última vez que funcionó fue en 1917.

Desde la primera Constitución, de 1821, se establecieron mecanismos electorales para elegir representantes populares para integrar el Gobierno y los Poderes Públicos. Incluso se realizaron elecciones para escoger el Representante ante las Cortes de Cádiz de 1812. En este sentido se fueron ampliando los electores, se fueron eliminando los requisitos excluyentes y de control público que existían hasta llegar al sistema de voto personal, directo, secreto y universal.

Igualmente, en todas las constituciones se han tratado aspectos de la división política administrativa del Estado y de la República. En todas se han señalado las formas del Juramento Constitucional, aspectos relacionados con educación, Hacienda y de la formación de las leyes.

El conjunto de Constituciones Políticas que hemos tenido ha tenido que ver también con el desarrollo del Derecho costarricense, con sus propios códigos normativos, especialmente a partir del Código General de Carrillo y la promulgación de Leyes que se ha realizado desde la constitución del Primer Poder Legislativo en el país, enriquecido este proceso con la promulgación del Código de Comercio de 1852, y los Códigos que resultaron de la Comisión Codificadora de 1882-1888.

\section{(ब) (O०)}

La Revista Estudios es editada por la Universidad de Costa Rica y se distribuye bajo una Licencia Creative Commons Atribución-NoComercial-CompartirIgual 3.0 Costa Rica. Para más información envíe un mensaje a revistaestudios.eeg@ucr.ac.cr. 


\section{Especial: Profesores de Estudios Generales Investigan}

La nueva Constitución de 1949, de la cual celebramos su 70 aniversario, nos ha dado el marco de tranquilidad y estabilidad nacional que la vida democrática electoral del país ha tenido desde ese año, sobre todo con la creación constitucional del Tribunal Supremo de Elecciones, con rango de Poder Público, por reforma constitucional realizada en 1975, igual al Poder Ejecutivo, a la Asamblea Legislativa y a la Corte Suprema de Justicia. Alto Tribunal que también cumple 70 años, con la delicada función de organizar, administrar, dirigir todo lo concerniente a procesos electorales y declarar resultados, sin apelación alguna, con absoluta independencia institucional, así como de asumir bajo su potestad y mandato a toda la fuerza pública, policial, del país durante los períodos electorales.

La Constitución de 1949 establece el reconocimiento del voto de la mujer, de igualdad de las mujeres en sus derechos políticos con los hombres, al declararse el voto universal.

Esta lucha de hecho se había iniciado débilmente en 1889 cuando el propio Presidente de la República, José Joaquín Rodríguez, en reconocimiento del papel que las mujeres jugaron en la defensa del sufragio de ese año, en las jornadas del 7 de noviembre, creyó válido que se reconociera ese derecho. El propio Presidente Rodríguez señaló que se debía hacer el "reconocimiento del derecho de voto", que hasta ese momento no se hacía. No lo logró.

Durante los siguientes años se siguió planteando este reconocimiento del derecho político de las mujeres. En la Asamblea Constituyente de 1917, en el gobierno de Federico Tinoco se discutió esto sin que se aprobara. Para esos tiempos ya habían surgido en el país movimientos sufragistas impulsados por mujeres, luchas que se mantuvieron de distintas maneras hasta la década de 1940-1950, que culminaron en la Asamblea Nacional Constituyente de 1949 proclamando este Derecho de Voto de la mujer costarricense, con el establecimiento del Voto Universal.

\section{(a) $(\Theta \odot$}

La Revista Estudios es editada por la Universidad de Costa Rica y se distribuye bajo una Licencia Creative Commons Atribución-NoComercial-CompartirIgual 3.0 Costa Rica. Para más información envíe un mensaje a revistaestudios.eeg@ucr.ac.cr. 


\section{Especial: Profesores de Estudios Generales Investigan}

\section{La situación electoral antes de 1948}

El Tribunal Supremo de Elecciones con la aprobación de la Constitución Política, el 7 de noviembre de 1949, cumplió 70 años de existencia. Este aniversario lo es desde 1975 como Poder Público, con igualdad de rango que el Poder Ejecutivo, el Legislativo y el Judicial.

El Tribunal Supremo de Elecciones es el resultado de la evolución histórica del sufragio y de los procesos electorales de Costa Rica.

Las Elecciones en Costa Rica que se pueden considerar las más antiguas, las que eligieron al Diputado Florencio del Castillo ante las Cortes de Cádiz, en 1812.

Durante el siglo XIX se desarrollaron procesos electorales para nombrar autoridades públicas y locales, con restricciones y exclusiones respecto a personas. No podían votar mujeres y analfabetos. Se exigía cierta capacidad económica. El voto era indirecto hasta 1913, al eliminarse el sistema de electores de segundo grado, y era público hasta 1924, al establecerse el voto secreto.

Antes de 1913 funcionó el Colegio Electoral, como sistema electoral y se reestableció durante la Constitución de 1917.

El 6 de agosto de 1913 se aprobó la Ley No. 79, "Ley de Elecciones", todavía con restricciones de voto a los mayores de 20 años, 18 si eran casados o si eran "profesores de alguna ciencia", que poseyeran alguna propiedad u oficio honesto cuyos frutos o ganancia sea suficientes...", sin ejercer el voto "las mujeres". Solo votaban los "hábilmente calificados para votar". Los resultados electorales eran por mayoría absoluta.

Para la organización de elecciones se creaban Juntas Electorales por Provincia, Cantón y distrito. Las Juntas Provinciales las nombraba el Presidente de la República. Verificaban el recuento de las votaciones, declaraban provisionalmente sus resultados y comunicaban los resultados al Secretario (Ministro) de

\section{(c) (i) (2)}

La Revista Estudios es editada por la Universidad de Costa Rica y se distribuye bajo una Licencia Creative Commons Atribución-NoComercial-CompartirIgual 3.0 Costa Rica. Para más información envíe un mensaje a revistaestudios.eeg@ucr.ac.cr. 
Especial: Profesores de Estudios Generales Investigan

Gobernación y a los Secretarios del Congreso, y depositar en este Ministerio la documentación respectiva.

Por competencia el Congreso conocía y decidía sobre reclamaciones que se hicieran del proceso electoral, calificar, escrutar las votaciones y declarar la elección.

Hasta 1946 en la Secretaría de Gobernación estaba el Registro de Estado Civil y el Electoral, el de empadronamiento de votantes, así llamado, Registro Cívico.

En 1925 se creó el Consejo Nacional de Electores, que se considera un antecedente del Tribunal Supremo de Elecciones.

En 1936 se determinó el 40\% de los votos válidamente emitidos para declarar resultados de las votaciones.

En 1946, el 27 de marzo, se aprobó el Código Electoral, que pasó a regular todos los procesos electorales, creó el Tribunal Nacional Electoral, integrado por representantes de los tres Poderes del Estado. Exigía que para ser elector se supiera leer y escribir, y señala al Tribunal Supremo de Elecciones (Art. 10) como el órgano que regula las elecciones y declara provisionalmente sus resultados, hasta que el Congreso no se pronuncie sobre sus resultados. Los tres magistrados que lo integraban eran nombrados por los Poderes Públicos. Se permitía que un candidato pudiera ser "común" en varios partidos, con acuerdo de sus asambleas nacionales.

La Junta Fundadora de la Segunda República reconoció al Tribunal Supremo de Elecciones al darle renta especial para sus gastos proveniente de los ingresos de la Fábrica Nacional de Licores y dictó el Reglamento para la Oficina de Presupuesto y Proveeduría del TSE.

Sin embargo, en el Decreto Ley No. 151, de 3 de setiembre de 1948, la Junta Fundadora de la Segunda al convocar a elecciones para integrar la Asamblea Nacional Constituyente, habla de que el Tribunal Nacional Electoral hará la declaratoria de resultados, y el 14 de setiembre de 1948, por medio del Decreto

\section{(c) (i) (2) (2)}

La Revista Estudios es editada por la Universidad de Costa Rica y se distribuye bajo una Licencia Creative Commons Atribución-NoComercial-CompartirIgual 3.0 Costa Rica. Para más información envíe un mensaje a revistaestudios.eeg@ucr.ac.cr. 


\section{Especial: Profesores de Estudios Generales Investigan}

Ley N. 171, señala que en lo sucesivo se le llame Tribunal Supremo de Elecciones.

De este modo, es en la Asamblea Nacional Constituyente cuando se crea el Tribunal Supremo de Elecciones como el órgano encargado de la dirección, vigilancia, de forma exclusiva, con total independencia, de todos los actos relativos al sufragio, con nombramiento de tres magistrados por parte de la Corte Suprema de Justicia.

Culminó el proceso en 1975, el 5 de junio, cuando se aprobó la reforma constitucional que hizo del Tribunal Supremo de Elecciones un Poder de Estado, con igual rango e independencia que los otros poderes públicos, constituyendo desde ese momento un pilar más, quizá el más sólido y garante, de la Democracia política representativa costarricense.

\section{¿Contra Reforma lo sucedido en $1948 ?$}

Que recuerde no se ha hablado de "contra reforma", por los resultados reales de lo sucedido, para referirse a los sucesos armados como un movimiento contra las Reformas Sociales impulsadas y el Código de Trabajo, principalmente en 1943, en el gobierno de Rafael Ángel Calderón Guardia, aliado en ese momento con el Partido Comunista, que cambió de nombre por Vanguardia Popular, a solicitud de la Iglesia Católica, que también participó de esa alianza política, y que se proyectó a la coalición política electoral "Bloque de la Victoria", con que participaron en las elecciones de 1943-1944 los partidos Republicano Nacional y Vanguardia Popular. Tampoco fue "contra reformas" del Gobierno de Teodoro Picado Michalski, como la Tributaria y la Electoral, ambas de 1946. El Gobierno de Picado Michalski era cuestionado por la oposición por otras razones.

Tampoco se ha justificado hablar de "contra reforma" porque la Asamblea Nacional Constituyente, convocada por el Gobierno de Facto, de la Junta

\section{(c) $)$ (i) (2)}

La Revista Estudios es editada por la Universidad de Costa Rica y se distribuye bajo una Licencia Creative Commons Atribución-NoComercial-Compartirlgual 3.0 Costa Rica. Para más información envíe un mensaje a revistaestudios.eeg@ucr.ac.cr. 


\section{Especial: Profesores de Estudios Generales Investigan}

Fundadora de la Segunda República, presidido por José Figueres, mantuvo y amplió el Capítulo de las Garantías Sociales de 1943 y se mantuvo también el Código de Trabajo de 1943, como se mantuvo el Código Electoral de 1946, en el que habían influido los comunistas en su elaboración.

Las acciones dictatoriales de la Junta se orientaron a suspender la Constitución Política de 1871, a gobernar mediante Decretos Leyes, casi mil promulgó, a suspender el funcionamiento del Poder Legislativo, a suspender el ejercicio a actividades políticas, a destituir los magistrados de la Corte Suprema de Justicia y nombrar nuevos Magistrados por Decretos Ley, a integrar Tribunales Especiales, de Probidad y Sanciones Inmediatas, a suspender las autoridades municipales en todo el país y nombrar nuevas por Decretos Ley, a desconocer lo Pactado en Ochomogo y en la Embajada de México, e iniciar la gran represión política y encarcelamiento de personas que estuvieron con el Gobierno de Calderón Guardia y Picado Michalski, de militantes comunistas, de obligar a la salida del país a gran cantidad de dirigentes políticos y militantes caldero-comunistas porque no les garantizaban sus vidas, a cerrar periódicos como "la Tribuna", "Trabajo" y la radioemisora "Ecos del 56", principalmente. Estas fueron entre muchas de las acciones represivas que realizó la Junta de Gobierno.

El punto negro y neurálgico de esos días fue el Decreto No. 105, de 17 de julio de 1948 y el Segundo párrafo del Artículo 98 de la Constitución, con los cuales se ilegalizó e impidió la participación electoral de los comunistas hasta 1975 formalmente. Seguido a esto fue la disolución de la Confederación de Trabajadores de Costa Rica, en agosto de 1948, hecha por el Padre Núñez, Ministro de Trabajo de la Junta.

A ello se sumó la expropiación de bienes, negocios y viviendas de calderonistas. Y, en diciembre de 1948, el asesinato, con conocimiento de la Junta de Gobierno, de los dirigentes comunistas de Limón, entre ellos de Federico Picado Sáenz, diputado electo en febrero de 1948, en el recodo del Río Reventazón, llamado

\section{(c) (i)(2) (2)}

La Revista Estudios es editada por la Universidad de Costa Rica y se distribuye bajo una Licencia Creative Commons Atribución-NoComercial-CompartirIgual 3.0 Costa Rica. Para más información envíe un mensaje a revistaestudios.eeg@ucr.ac.cr. 


\section{Especial: Profesores de Estudios Generales Investigan}

Codo de Diablo, siendo el autor intelectual de este crimen Gonzalo Facio Segreda. Así lo relató Edgar Cardona cuando Con motivo del intento de Golpe de Estado que impulsó contra la Junta de Gobierno, José Figueres al detenerlo lo encerró en la Penitenciaría Central, donde estaban los comunistas y allí él reveló esta autoría intelectual del crimen del Codo del Diablo.

Se ha hablado, por parte de los comunistas, más que de contra reforma de "la reacción contra las Reformas Sociales", como justificante de los acontecido en marzo y abril de 1948, como uno de los elementos, el más importante para ellos, que movilizó a los sucesos armados a los insurgentes, en tanto las fuerzas rebeldes justificaron su accionar en función del respeto al sufragio, contra el fraude electoral y por el reconocimiento del triunfo electoral del Presidente Otilio Ulate Blanco en esas elecciones de 1948.

Así, defensa de las Garantías Sociales y del Código de Trabajo de 1943 y la pureza electoral y la defensa del sufragio se han convertido en los dos grandes elementos conceptuales que se movieron alrededor de los sucesos armados de marzo y abril de 1948.

El respeto al sufragio era un tema que se lo traía la oposición política desde las elecciones de 1944, en las cuales resultó triunfante Teodoro Picado Michalski, alegando fraude en ese triunfo. Y, José Figueres, quien había sido expulsado del país por el Gobierno de Calderón Guardia, justificó que el Gobierno de Teodoro Picado Michalski debía caerse por la fuerza al haber resultado ilegítimamente electo, como resultado de un fraude. José Figueres era de la tesis de tumbar al gobierno por la vía militar, para lo que empezó a prepararse, en el entendido de que, si en las elecciones de 1948 volvía a repetirse el fraude, entonces se levantaría en armas, como lo hizo.

Si no desarrolló su lucha armada contra el Gobierno de Teodoro Picado Michalski fue porque Otilio Ulate Blanco, a la muerte de León Cortés, en 1946, cuando

\section{(c) (i) (-)}

La Revista Estudios es editada por la Universidad de Costa Rica y se distribuye bajo una Licencia Creative Commons Atribución-NoComercial-CompartirIgual 3.0 Costa Rica. Para más información envíe un mensaje a revistaestudios.eeg@ucr.ac.cr. 


\section{Especial: Profesores de Estudios Generales Investigan}

asumió la Jefatura política de la oposición, se lo impidió, condicionándole dicha acción al resultado de las elecciones de 1948.

Aun así no impidió, que en los días políticamente convulsos de 1946 y 1947, José Figueres y sus hombres, impulsaran acciones terroristas y mediáticas, de distinto tipo, contra los comunistas y gobiernistas, poniendo gran tensión en esos meses, hasta la víspera de las elecciones, pasando por la Huelga de Brazos Caídos, que desde el 22 de julio al 2 de agosto mantuvieron presionando por el control de la Fuerza Pública y del aparato electoral, para garantizar neutralidad del gobierno y pureza electoral.

Resultado de esa huelga el aparato electoral terminó controlándolo la oposición para esas elecciones. De allí también el embrollo del resultado electoral que el Congreso anuló, en la decisión presidencial, no así en la elección de diputados donde había habido un aumento de diputados gobiernistas y comunistas.

Así, en resumen, esos acontecimientos militares, de la Guerra Civil, en Costa Rica no se dieron como resultado de un "Golpe de Estado" contra el Gobierno constitucional de Teodoro Picado Michalski, acción que resulta de un movimiento sorpresivo, y repentino, por medio de un grupo político y armado o militar, con el propósito de quedarse con el Poder, violentando de esa forma los mecanismos legales y constitucionales de la sucesión presidencial.

En el Siglo XX solo hemos conocido el Golpe de Estado Institucional que se dio en enero de 1917 y que se prolongó hasta agosto de 1919, por parte del Ministro de Guerra, Federico Tinoco Granados, contra el Presidente Alfredo González Flores. No ha habido otro Golpe de Estado en la historia nacional después de ese.

Para mí, lo sucedido en 1948 no fue un Golpe de Estado, contra Teodoro Picado Michalski, como vengo oyendo y leyendo a algunas personas, especialmente de la izquierda política, que me merecen respeto, que sostienen este argumento. $\mathrm{Ni}$ siquiera se podría argumentar que fue un intento de Golpe de Estado que adquirió la forma de rebelión, sublevación o motín popular. Fue un alzamiento militar para

\section{(c) (i) (2)}

La Revista Estudios es editada por la Universidad de Costa Rica y se distribuye bajo una Licencia Creative Commons Atribución-NoComercial-CompartirIgual 3.0 Costa Rica. Para más información envíe un mensaje a 


\section{Especial: Profesores de Estudios Generales Investigan}

tratar de detener una decisión que había tomado el Congreso de la República, la anulación de la elección del presidente Otilio Ulate Blanco. No hubo una acción de desobediencia política colectiva ni de masas contra el gobierno, en esos días del enfrentamiento. Se dio el enfrentamiento militar alrededor del cual la gente y los ciudadanos se iban ubicando, en uno $u$ otro bando, o neutralizando ante ellos, para hacer respetar el resultado electoral a favor de Otilio Ulate Blanco.

Los Golpes de Estado por su naturaleza son de rápida ejecución y solución, no son de larga duración en su intento. El Golpe de Estado es de horas, no de varias semanas en su marcha o ejecución. El planeamiento de un Golpe de Estado sí puede llevar su tiempo.

El enfrentamiento dado produjo la situación de una guerra civil de corta duración, entre los dos bandos que terminaron enfrentados. Dichosamente este conflicto militar fue de corta duración, un mes, con un saldo de 3000 muertos aproximadamente, cifra también sujeta de discusión académica y necesaria de precisar aún.

Los sucesos ocurridos en esas semanas no ocasionaron tampoco un caos social que pudiera haber sido aprovechado masivamente por la población, de manera anárquica.

La llamada Junta Fundadora de la Segunda República no usó para su auto denominación el término de "Revolucionaria", a pesar de que hoy consideramos algunas de sus acciones institucionales, en esos dos años, de "revolucionarias", por sus alcances y profundidades institucionales.

La "Revolución" realizada por la Junta de Gobierno es parte de esa discusión, aún pendiente, en todo lo que este concepto pueda significar, partiendo del cambio profundo que pudo ocasionar su Gobierno, y de que "Revolución" puede asimilarse a "cambio radical", en tanto va a la raíz de la situación.

\section{(c) (i)(2)}

La Revista Estudios es editada por la Universidad de Costa Rica y se distribuye bajo una Licencia Creative Commons Atribución-NoComercial-CompartirIgual 3.0 Costa Rica. Para más información envíe un mensaje a revistaestudios.eeg@ucr.ac.cr. 


\section{Especial: Profesores de Estudios Generales Investigan}

El resultado de los enfrentamientos militares de esos días, de 1948, ni siquiera provocaron el desplazamiento de las autoridades de Gobierno que había asumido sus riendas en 1944.

El presidente Teodoro Picado Michalski no fue depuesto y no renunció a su mandato, que era lo que exigía José Figueres en esos últimos días de abril de 1948. Trasladó el ejercicio de su Presidencia al Designado Santos León Herrera quien terminó ese ejercicio constitucional, y fue quien le entregó el Gobierno a José Figueres, según lo había impuesto José Figueres y Ulate Blanco, en el Pacto firmado por ellos el 1 de mayo de 1948.

Teodoro Picado Michalski, dígase lo que se diga, no fue un dictador. Como persona ha sido uno de los más ilustres presidentes que han gobernado el país.

Los comunistas oficialmente nunca dijeron durante esos días aciagos de marzo y abril del 48 que se intentaba un Golpe de Estado. Tampoco en los años siguientes, de manera oficial, sostuvieron esa tesis del Golpe de Estado alrededor de esos sucesos. Siempre hablaron de la "Guerra Civil" sufrida en el país. Eso fue lo que tuvimos.

El saldo de ella se cerró con la promulgación de la Constitución Política de 1949, con ello se cerró el capítulo de la Dictadura de José Figueres con su Junta de Gobierno, con ello se inició el período histórico de la Segunda República bajo las banderas del constitucionalismo surgido con la Constitución Política de 1949 y el régimen republicano, democrático y representativo que ha descansado hasta ahora en 17 procesos electorales incuestionados desde entonces. Nos dejó un país sin ejército con graves tendencias, a veces militaristas en su Fuerza Pública. La celebración del 70 aniversario de la Constitución Política nos recuerda que la actual Costa Rica se definió en este documento que establece los límites del ejercicio del gobierno y abre ampliamente el ejercicio de los Derechos y Libertades de los ciudadanos, que son irrenunciables.

\section{(a) $(\mathbb{Q} \Theta$}

La Revista Estudios es editada por la Universidad de Costa Rica y se distribuye bajo una Licencia Creative Commons Atribución-NoComercial-CompartirIgual 3.0 Costa Rica. Para más información envíe un mensaje a 


\section{Especial: Profesores de Estudios Generales Investigan}

La Constitución Política de 1949 es el Pacto Social que nos regula hoy, es el sistema de coordenadas del desarrollo institucional y el que marca a cada Gobierno en la necesidad de impulsar el anhelo de lograr la mayor felicidad y el mayor bienestar posible para todos los ciudadanos y habitantes de Costa Rica.

Asimismo, se crearon una serie de instituciones como el Tribunal Supremo de Elecciones, la Contraloría General de la República, la Dirección del Servicio Civil, la Procuraduría General de República, los principios constitucionales presupuestarios, tan importantes en nuestra vida democrática.

Nos dejó la Constitución Política un sólido Estado de Derecho que se ha ido modernizando hacia el llamado Estado Social y Democrático de Derecho.

La Constitución Política del 49 dejó un Poder Judicial más sólido, más independiente, hoy amenazado con la reforma para el nombramiento de sus Magistrados que se pretende en la actual Asamblea Legislativa.

La Constitución de 1949 resalta la Democracia como sistema de vida y sistema político que hoy disfrutamos los costarricenses.

\section{(c) (i) (9) (2)}

La Revista Estudios es editada por la Universidad de Costa Rica y se distribuye bajo una Licencia Creative Commons Atribución-NoComercial-CompartirIgual 3.0 Costa Rica. Para más información envíe un mensaje a 